\title{
Woodpecker Nest Tree Characteristics in Upper Midwestern Oak Forests
}

\author{
Collette L. AdKins Giese ${ }^{1,2}$ and Francesca J. Cuthbert
}

Department of Fisheries, Wildlife, and Conservation Biology, 1980 Folwell Avenue, University of Minnesota, St. Paul, Minnesota 55108 USA

${ }^{1}$ Present address: $5415-134^{\text {th }}$ Street North, Hugo, Minnesota 55038 USA

${ }^{2}$ Corresponding author: e-mail: adki0020@umn.edu

Adkins Giese, Collette L., and Francesca J. Cuthbert. 2005. Woodpecker nest tree characteristics in Upper Midwestern Oak forests. Canadian Field-Naturalist 119(3): 367-376.

Characteristics of woodpecker nest trees have been widely studied in some regions of North America. However, there is little research from the Upper Midwest. Forest managers need information on woodpecker nest tree characteristics so they can recommend leaving during harvest trees that meet the needs of cavity-dwelling wildlife. Information specific to the Upper Midwest is especially important given that declines in several species of cavity nesting birds have been predicted by an environmental analysis of timber harvest in Minnesota. Our purpose was to identify attributes of nest trees used by primary cavity-nesting birds. We compared nest trees to unused trees and examined differences in nest trees among woodpecker species. We found 166 active woodpecker nests in upper midwestern oak forests in 1997 and 1998. For each nest tree, we recorded height, diameter, status, and aspects of tree decay. We also measured four potential nest trees (non-nest trees, within size requirements of cavity-nesting birds, with $\geq 2$ indicators of heartwood decay) closest to each active nest tree. Additionally, we recorded these measurements for 137 randomly selected potential nest trees. Using paired $t$-tests and chi-square analysis, we found each woodpecker species had a unique set of characteristics that separated nest trees from potential nest trees. Using an extension of the McNemar test for related samples, we found woodpeckers as a group used trees that were larger, both in diameter and height, more often elm (Ulmus americana, U. rubra) or aspen (Populus tremuloides, P. grandidentata), more likely to have old cavities present, and with more decay indicators than adjacent potential nest trees. The Yellow-bellied Sapsucker (Sphyrapicus varius) differed from the other woodpecker species by nesting in living Trembling Aspens (Populus tremuloides) with intact tops, complete bark cover, and heartwood fungus. Diameters of nest trees differed significantly among woodpecker species, but unlike findings from other studies, the height of nest hole and nest tree did not. Woodpecker nest entrances faced south or southeast significantly more often than by chance alone, even when excluding leaning trees. This study suggests that generic forest management for all woodpecker species may not be adequate because individual species have specific nest tree requirements. Management recommendations for cavity-nesting birds need to be tailored to meet the needs of a diversity of species.

Key Words: Woodpeckers, nest site selection, oak forests, timber management, Minnesota.

Woodpeckers play a key role in forest communities. The unique ability of woodpeckers to excavate holes in trees for nesting and roosting creates habitat for many other species of cavity-dwelling wildlife. Additionally, as predators of forest insects, woodpeckers may help control insect outbreaks (Bruns 1960). These natural history traits should make conservation of this group a priority in forest management. Declines in the numbers of several species [e.g., Barred Owl (Strix varia), Boreal Owl (Aegolius funereus), Northern Saw-whet Owl (Aegolius acadicus), Yellow-bellied Sapsucker (Sphyrapicus varius), American Three-toed Woodpecker (Picoides dorsalis), Black-backed Woodpecker (Picoides arcticus), Pileated Woodpecker (Dryocopus pileatus), Great-crested Flycatcher (Myiarchus crinitus), Black-capped Chickadee (Parus atricapillus), Boreal Chickadee (Poecile hudsonica), Redbreasted Nuthatch (Sitta canadensis), and White-breasted Nuthatch (Sitta carolinensis)] of cavity-nesting birds have been predicted in the Upper Midwest (Generic Environmental Impact Statement on Timber Harvesting in Minnesota 1994, Minnesota Environmental Quality Board, St. Paul.
Without knowledge of specific habitat requirements of cavity-nesting birds, conservation of these species is difficult. Information on woodpecker nest trees has important implications for forest management, including which trees are best to leave for wildlife during harvest and whether general guidelines are suitable for all species.

Only certain trees are suitable for woodpecker excavation. The tree must be large enough to support a nest, but selected tree size depends on woodpecker body size (Conner et al. 1975). In general, trees larger in diameter and height are used more often than smaller trees (Welsch and Howard 1983; Zarnowitz and Manuwal 1985). Woodpeckers also require trees with heartwood decay (Kilham 1971; Conner et al. 1976), which is caused by fungal invasion of the inner wood; decay softens the wood and facilitates excavation. Consequently, woodpeckers often choose dead or dying trees for nest hole excavation. However, some tree species (e.g., Populus spp.) can contain suitable heartwood decay while they are still alive (Kilham 1971; Runde and Capen 1987). Woodpeckers are not restricted to certain tree species for nesting. However, some 


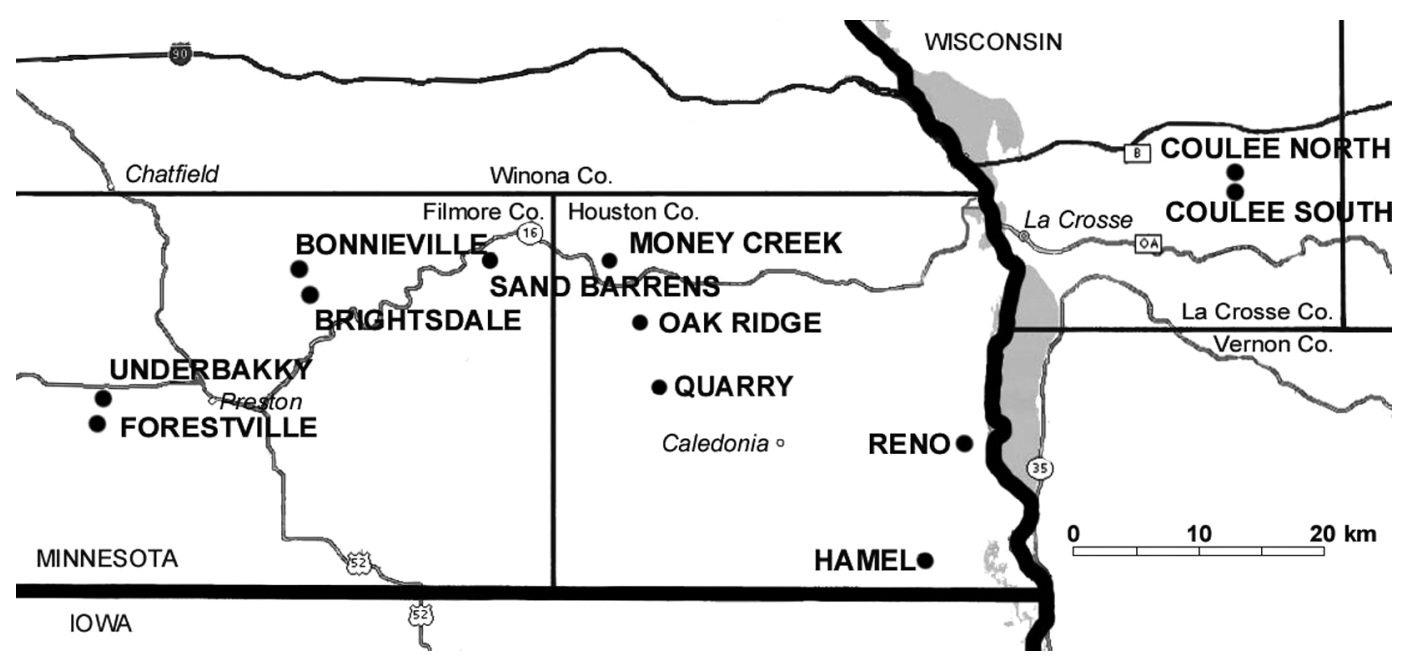

FIGURE 1. Map of Houston and Fillmore counties of Minnesota and La Crosse County of Wisconsin showing locations of 12 woodpecker nest tree study plots in upper midwestern oak forests, 1997-1998.

tree species are preferred substrates for woodpecker nest excavation (Thomas et al. 1979).

The characteristics of nest trees used by woodpeckers have been widely studied in some regions of North America. Research on woodpecker nest site selection in the western United States is most extensive (McClelland and Frissel 1975; Bull and Meslow 1977; Scott 1978; Scott et al. 1978; Mannan et al. 1980; Scott et al. 1980; Scott and Oldemeyer 1983; Winternitz and Cahn 1983; Raphael and White 1984; Zarnowitz and Manuwal 1985; Sedgewick and Knopf 1986, 1990; Li and Martin 1991; Schreiber and deCalesta 1992; Dobkin et al. 1995).

Outside the western U.S., fewer researchers have examined characteristics of nest trees used by woodpeckers. Studies have been done in northern hardwood forests of Vermont, New York, and New Hampshire (Kilham 1971; Swallow et al. 1986; Runde and Capen 1987). Other research was conducted in oakhickory forests of southwestern Virginia (Conner 1975; Conner et al. 1975, 1976; Conner and Adkisson 1977). Only a few studies focused on the Upper Midwest, including oak-hickory forests of east-central Illinois (Reller 1972) and riparian areas in Iowa (Stauffer and Best 1982).

Because characteristics of snags vary widely among biotic communities (Zeedyk 1983), information from other regions may not be applicable to upper midwestern oak forests. Geographically specific information on nest tree requirements of woodpeckers is needed to develop regional forest management guidelines for cavity-nesting birds.

The objective of our study was to identify attributes of nest trees used by primary cavity-nesting birds (woodpeckers). We address the following questions: (1) Do trees chosen for nesting by woodpeckers differ from unused trees in terms of tree size, tree condition, and tree species? (2) Are there differences among woodpecker species in nest tree size, tree condition, and tree species?

\section{Methods}

Study Area

Our study area was located in Houston $\left(43^{\circ} 40^{\prime} \mathrm{N}\right.$, $\left.91^{\circ} 30^{\prime} \mathrm{W}\right)$ and Fillmore $\left(43^{\circ} 40^{\prime} \mathrm{N}, 92^{\circ} 05^{\prime} \mathrm{W}\right)$ counties, southeastern Minnesota, and LaCrosse County $\left(43^{\circ} 19^{\prime} \mathrm{N}, 91^{\circ} 27^{\prime} \mathrm{W}\right)$, western Wisconsin, United States (Figure 1). This area was uncovered by the Wisconsin Glaciation and is referred to as the Driftless Area. The pre-settlement vegetation was oak woodland and brushland and maple-basswood forest (Marschner 1974). The landscape has become highly fragmented, consisting primarily of oak forest patches surrounded by agricultural lands.

We selected plots from available state-owned forests (Richard J. Dorer Memorial State Hardwood Forest, Forestville State Park, and Coulee State Experimental Forest) on the basis of accessibility and intensity of public use. The plots were widely scattered: the westernmost and easternmost plots were approximately $90 \mathrm{~km}$ apart. We studied 12 plots (8 plots each year; for maps see Adkins Giese 1999). Plots were 28-40 ha (mean $=36$ ha $)$.

The study area has a varied disturbance history including logging, grazing, and fire. None of the plots was logged in the last ten years; however, firewood cutting was allowed at one site. Only the Quarry plot, which included some private land, was grazed in the last ten years. Some plots were in forest fragments as small as $40 \mathrm{ha}$, while others were within more extensive forest tracts.

All plots were in closed-canopy mature forest, ranging in age from 80 to 120 years. The canopies were dominated by oaks (Quercus rubra, Q. alba, Q. bicol- 
or) (30 percent of all trees sampled), but also included hickories (Carya ovata, C. cordiformis) (13 percent), elms (17 percent), basswood (Tilia americana) (8 percent), aspen (6 percent), other hardwoods, and some White Pine (Pinus strobus). Young plants of these canopy trees and hazel (Corylus spp.), gooseberry (Ribes spp.), and raspberry (Rubus spp.) made up the woody understory. We provide additional details on habitat structure and composition in another paper (Adkins Giese and Cuthbert 2003), which focuses on the broader habitat needs of woodpeckers. Breeding bird surveys found that the plots had 56 bird species, including 13 cavity-nesting species (M. Friberg, University of Minnesota, personal communication).

We marked the plots with flagging tape, forming a grid used to plot locations of woodpecker activity on field maps, mark nest locations, and specify locations for the randomly selected sites.

\section{Nest Searching}

In 1997, we began searching for nests 6 May and stopped 23 June. In 1998, we began searching for nests 20 April and stopped 22 June. After formal nest searching ended, we opportunistically located additional nests during vegetation surveys.

We searched for active nests of all primary cavitynesting birds on the plots, excluding the Black-capped Chickadee. The primary cavity-nesting birds included Downy (Picoides pubescens), Hairy (P. villosus), Redbellied (Melanerpes carolinus), Red-headed (M. erythrocephalus), and Pileated woodpeckers, Yellowbellied Sapsuckers, and Northern Flickers (Colaptes auratus).

We found nests by following woodpecker vocalizations, drumming, and flight paths. We found additional nests by systematically walking the plots and examining trees with cavities and fresh chips at the base. Our goal was to find as many nests as possible, rather than to make plot comparisons, thus there was no attempt to equalize nest-searching efforts across plots. We included nests found outside plots as long as they were within the study area. We found nests of the Red-headed Woodpecker along roadsides, as well as on the plots.

We considered nests to be active if we observed any of the following: (1) adult completely entering cavity and remaining for over 10 minutes; (2) adult flushed from cavity; (3) adult feeding young; and (4) young calling from cavity. Because of difficulty locating Red-headed Woodpecker nests, an adult repeatedly entering a cavity but not remaining inside was considered sufficient evidence of nest activity.

\section{Vegetation Surveys}

We recorded characteristics of all active woodpecker nest trees found. For comparison, we also obtained vegetation measurements for the four closest potential nest trees and a sample of randomly selected potential nest trees. Potential nest trees were defined as non-nest trees, within the height and diameter requirements of cavity-nesting birds, with $\geq 2$ indicators of heartwood decay (Conner 1978). Decay indicators included old cavities, tree scars, branch stubs, fungal conks, and significant dead portions. Potential nest trees were not presently used by woodpeckers, but some had indications of previous use. In accordance with the minimum nest height and tree diameter used by woodpeckers, potential nest trees were $>15.2 \mathrm{~cm}$ diameter at breast height (dbh) and $>1.8 \mathrm{~m}$ tall (Thomas et al. 1979). We modified the study methods after Runde and Capen (1987).

We recorded vegetation characteristics to describe tree size, tree condition, and tree species of nest trees and potential nest trees (Table 1). To describe tree size, we recorded tree height and dbh. To describe the tree condition, we recorded tree status, top condition, limb condition, presence of decay indicators, and percentage live wood and bark cover in quartile classes. For consistency, the same person took all subjective vegetation measurements.

To determine the availability of trees of various sizes and species for nesting and to get a sample of randomly selected potential nest trees, we sampled trees in circular subplots (11.3 m radius) randomly distributed across the plots. For all trees within the subplots, we recorded species, status, and size class. From subplots that contained potential nest trees, one potential nest tree was randomly chosen for comparison to nest trees $(n=137)$.

\section{Data Analysis}

We compared nest trees to potential nest trees to evaluate woodpecker nest tree selection. Comparisons of nest trees among the woodpecker species were also made to determine interspecific similarities and differences. Alpha levels $<0.05$ were used to indicate significance.

We statistically compared size, condition, and species of nest trees to adjacent potential nest trees. By using adjacent potential nest trees, rather than randomly selected potential nest trees, we could assess how the nest tree differed from other trees within the chosen nest area. We used paired $t$-tests to compare dbh and height of nest trees to the mean of four adjacent potential nest trees. Because data for available trees were categorical, with diameter based on size class, we used chi-square to compare the diameter of nest trees to available trees. An extension of the McNemar test for related samples (Miettinen 1968) was used to compare the condition and species of all woodpecker nest trees to the related sample of adjacent potential nest trees. Using the McNemar extension, we established comparisons using 2 or 3 categories for each independent variable.

Because of high skew and small sample size, the extension of the McNemar test could not be used when comparing the condition and species of nest trees to potential nest trees for each individual woodpecker species. Instead, we used chi-square tests of homo- 
TABLE 1. Descriptions of vegetation measurements taken for woodpecker nest trees and potential nest trees in upper midwestern oak forests, 1997-1998.

\begin{tabular}{|c|c|c|}
\hline Variable & Categories & Description \\
\hline Tree status & Alive, Dead, Partly Dead & $\begin{array}{l}\text { Partly dead: tree forked with only } 1 \text { fork dead or tree } \\
\text { with only small remaining living branches ( }>75 \% \text { dead) }\end{array}$ \\
\hline Tree height & N/A & Measured using a clinometer \\
\hline Top condition & $\begin{array}{l}\text { Top intact, Top broken, } \\
\text { Broken fork }\end{array}$ & $\begin{array}{l}\text { Top broken: tree top ends abruptly. Broken fork: trunk } \\
\text { split with } 1 \text { fork intact and } 1 \text { broken }\end{array}$ \\
\hline Limb condition & $\begin{array}{l}\text { Trunk, Main branches, Secondary } \\
\text { branches, Foliage twigs }\end{array}$ & $\begin{array}{l}\text { Smallest type of branches remaining, regardless of } \\
\text { whether branches were dead or alive }\end{array}$ \\
\hline $\begin{array}{r}\text { Percentage } \\
\text { live wood }\end{array}$ & $\begin{array}{r}0-25,>25-50 \\
>50-75,>75\end{array}$ & $\begin{array}{l}\text { A subjective estimate of percentage live wood in } \\
\text { quartile classes }\end{array}$ \\
\hline $\begin{array}{l}\text { Percentage } \\
\text { bark cover }\end{array}$ & $\begin{array}{r}0-25,>25-50 \\
>50-75,>75\end{array}$ & $\begin{array}{l}\text { A subjective estimate of percentage bark cover in } \\
\text { quartile classes }\end{array}$ \\
\hline $\begin{array}{l}\text { Heartwood } \\
\text { fungal conks }\end{array}$ & Presence, Absence & $\begin{array}{l}\text { Formes igniarius, the shelf fungus of Trembling Aspen, } \\
\text { and other large shelf fungi }\end{array}$ \\
\hline Sapwood fungus & Presence, Absence & Small, superficial tree fungi \\
\hline Old cavities & Presence, Absence & $\begin{array}{l}\text { Holes that looked as if they were completely excavated } \\
\text { by a woodpecker }\end{array}$ \\
\hline Trees scars & Presence, Absence & $\begin{array}{l}\text { Tree wounds with exposed heartwood (natural cavities, } \\
\text { excavation attempts, and deep foraging holes) }\end{array}$ \\
\hline $\begin{array}{l}\text { Significant } \\
\text { dead portions }\end{array}$ & Presence, Absence & $\begin{array}{l}\text { Dead portions large enough to be nesting substrate for } \\
\text { Downy Woodpecker ( }>15 \mathrm{~cm} \text { diameter; }>30 \mathrm{~cm} \text { long) }\end{array}$ \\
\hline Branch stubs & Presence, Absence & $\begin{array}{c}\text { Broken branch or stem }>15 \mathrm{~cm} \text { diameter and }>30 \mathrm{~cm} \text { long } \\
\text { or broken branch }<50 \mathrm{~cm} \text { on stem }>15 \mathrm{~cm} \text { diameter }\end{array}$ \\
\hline
\end{tabular}

geneity to compare nest trees to a randomly selected sample of potential nest trees. Because each independent variable had 2 or 3 categories, we set up $2 \times 2$ or $2 \times 3$ chi-square contingency tables, accordingly. If we found a significant difference within a $2 \times 3$ chisquare contingency table, we broke the table into nonindependent $2 \times 2$ tables for examination of where non-homogeneity occurred (Brunden 1972).

We also made comparisons among the woodpecker species for nest tree size, condition, and species. We used Kruskal-Wallis ANOVAs to compare the dbh and height of nest trees among the seven species of woodpeckers. When we found a significant difference among species, we used a multiple comparison procedure using rank sums to determine which species differed significantly from each other (Dunn 1964). To compare the condition and species of the nest tree among the species of woodpeckers, we used chi-square tests of homogeneity. The Northern Flicker and the Pileated Woodpecker were not included in comparisons among the woodpecker species because of small sample size.

\section{Results}

\section{Comparison of Nest Trees and Unused Trees}

We found 166 nests, including 76 in 1997 and 90 in 1998 (Table 2). Woodpecker nest trees had significantly greater diameter and height than adjacent potential nest trees (Table 3). Over 50\% of nest trees were 23$38 \mathrm{~cm}$ dbh (Figure 2). This diameter class was used out of proportion to its availability $\left(\chi^{2}=893, P<0.001\right.$, $\mathrm{df}=1)$.

The decay condition of active woodpecker nest trees also differed from potential nest trees. In comparison to adjacent potential nest trees, nest trees of all woodpecker species combined were less likely to have broken tops $(\mathrm{P}<0.05)$, were more likely to have foliagebearing twigs present $(\mathrm{P}<0.01)$, were more likely to have heartwood fungus present $(\mathrm{P}<0.01)$, were less likely to have significant dead portions present $(\mathrm{P}<0.05)$, had more total decay indicators present $(\mathrm{P}<0.001)$, and were more often elm or quaking aspen $(\mathrm{P}<0.001)$. Nest trees also were more likely to have old cavities present $(55 \%$ of nest trees versus $4 \%$ of potential nest trees), but the high skew invalidated the McNemar extension. These results were highly influenced by the large sample of Yellow-bellied Sapsuckers, which reflected the species' strong preference for living aspens with intact tops and heartwood decay (Table 4). When the Yellow-bellied Sapsucker was excluded, only number of decay indicators $(\mathrm{P}<0.01)$ and tree species elm or aspen $(\mathrm{P}<0.001)$ remained significant. The percentage of nest trees with old cavities still remained high $(51 \%$ of nest trees versus $8 \%$ of potential nest trees). There was no difference found between nest trees and potential nest trees in tree status, percentage live wood or bark cover, or in the presence of branch stubs or tree scars.

Certain tree species were frequently used for nesting by woodpeckers. Woodpeckers nested in American Elms (Ulmus americana) and Trembling (Quaking) Aspens much more often than expected based on availability $\left(\chi^{2}=391, P<0.001, \mathrm{df}=1\right)$. American Elm and Trembling Aspen provided $70 \%$ of all nest sites, but constituted only $10 \%$ and $5 \%$ of all trees in random plots, respectively. Dead American Elms made up $<1 \%$ of available trees and dead Slippery Elms (Ulmus rubra) made up approximately $1 \%$ of available trees. 


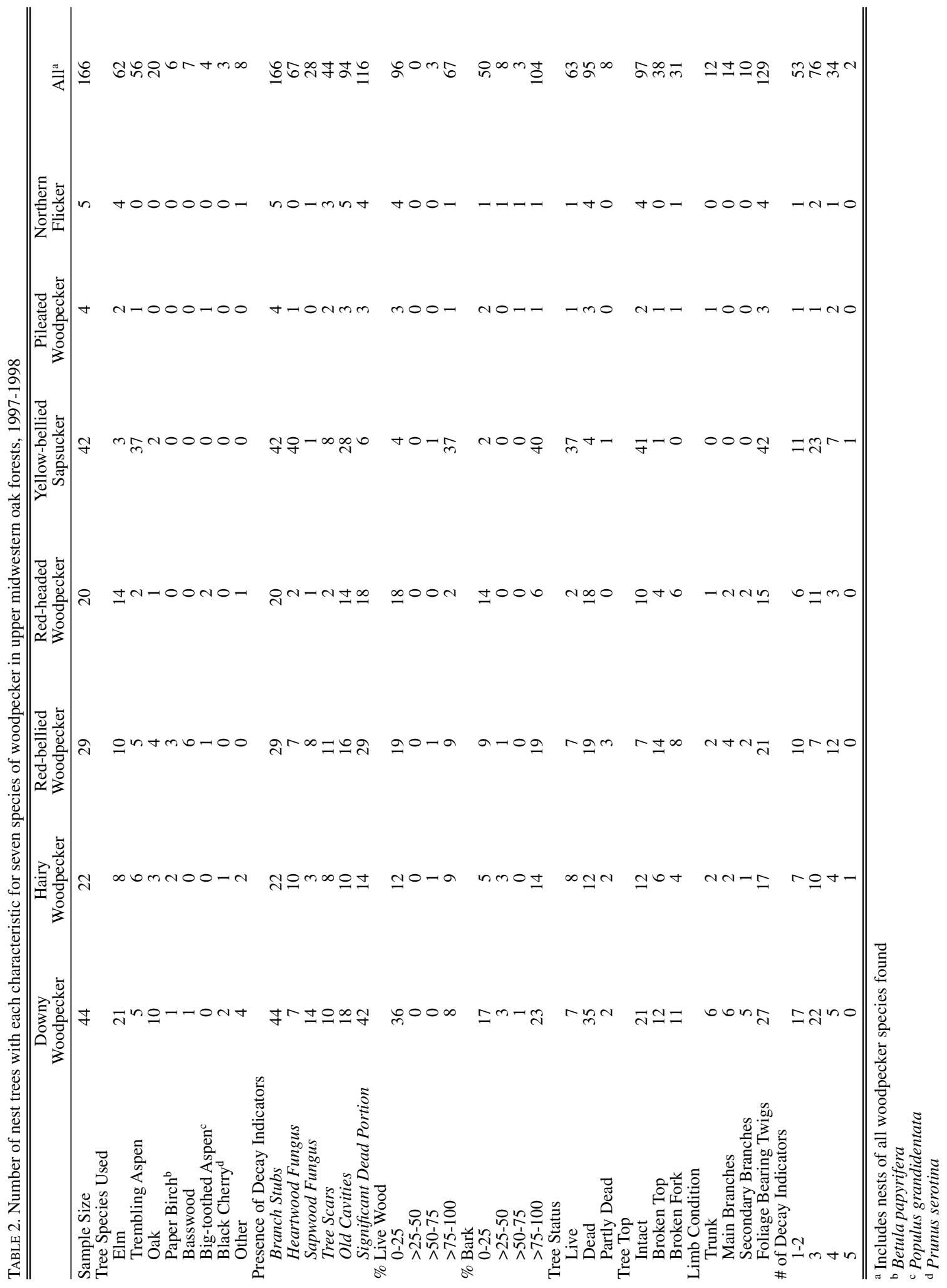


TABLE 3. Paired comparison of nest trees with mean of four adjacent potential nest trees for seven species of woodpecker in upper midwestern oak forests, 1997-1998.

\begin{tabular}{|c|c|c|c|c|c|c|c|c|c|c|}
\hline & \multicolumn{5}{|c|}{ Tree Diameter $(\mathrm{cm})$} & \multicolumn{5}{|c|}{ Tree Height (m) } \\
\hline & Diff. $^{a}$ & SE & $t$ & df & & Diff. & SE & $t$ & df & \\
\hline Hairy Woodpecker & -0.8 & 2.8 & -1.0 & 21 & NS & 2.8 & 1.3 & 2.1 & 21 & * \\
\hline Downy Woodpecker & -0.7 & 2.4 & -0.8 & 43 & $N S^{b}$ & 2.6 & 1.1 & 2.4 & 43 & * \\
\hline Yellow-bellied Sapsucker & 0.1 & 1.2 & 0.5 & 41 & NS & 5.2 & 0.8 & 6.2 & 41 & *** \\
\hline Red-bellied Woodpecker & 10.2 & 5.4 & 2.1 & 28 & $*$ & 4.3 & 1.4 & 3.1 & 28 & *** \\
\hline Red-headed Woodpecker & 17.0 & 4.7 & 4.5 & 19 & $* * *$ & 6.5 & 1.3 & 5.1 & 19 & *** \\
\hline Northern Flicker & 31.4 & 20.6 & 1.6 & 3 & NS & 4.7 & 1.4 & 3.4 & 3 & * \\
\hline Pileated Woodpecker & 39.9 & 19.7 & 3.4 & 3 & $*$ & 9.4 & 6.2 & 1.5 & 3 & NS \\
\hline All woodpecker nests & 5.3 & 1.6 & 2.3 & 164 & $* * *$ & 4.3 & 0.5 & 8.2 & 164 & ***** \\
\hline
\end{tabular}

${ }^{\text {a }}$ The difference of the means (Diff.) of nest tree and four adjacent potential nest trees (nest tree - adjacent)

${ }^{\mathrm{b}} \mathrm{NS} P>0.05$

${ }^{*} P<0.05$

${ }^{* *} P<0.01$

${ }^{* * *} P<0.001$

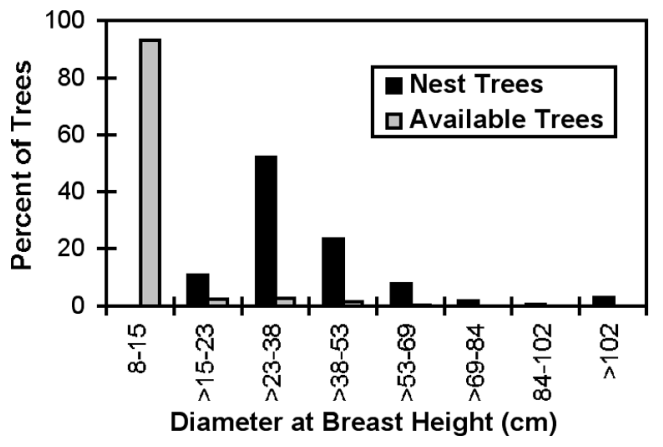

FIGURE 2. Diameter at breast height $(\mathrm{cm})$ in size classes for all woodpecker nest trees and available trees in upper midwestern oak forests, 1997-1998.

Each woodpecker species had a set of characteristics that differentiated its nest trees from randomly selected potential nest trees (Table 4). In comparison with random potential nest trees, nest trees of the Pileated Woodpecker were more often elm or Trembling Aspen $(P<0.001)$, with old cavities $(P<$ $0.001)$, more decay indicators $(P<0.001)$, and less bark cover $(P<0.01)$. Nest trees of the Northern Flicker were more often elm or Trembling Aspen $(P$ $<0.01)$, with old cavities $(P<0.001)$ and more decay indicators $(P<0.001)$.

\section{Comparison Among Woodpecker Species}

We wanted to determine if nest tree selection differed among species of woodpeckers. We found a significant difference among woodpecker species in nest tree dbh, but not nest tree height (Table 5). Many differences in nest tree condition among the woodpecker species were found (Table 6). The Yellow-bellied Sapsucker differed from the other woodpecker species by nesting in living Trembling Aspens with intact tops, complete bark cover, and heartwood fun- gus. No difference among the woodpecker species was found in limb condition, number of decay indicators, and presence of branch stubs, tree scars, and old cavities.

\section{Discussion}

\section{Tree Size}

Many investigators report that woodpecker nest trees are larger than unused snags (Bull and Meslow 1977; Welsch and Howard 1983; Zarnowitz and Manuwal 1985; Schreiber and deCalesta 1992). We compared nest trees to unused trees that met minimum size requirements. This allowed us to make a comparison with trees that are generally larger in diameter than a random sample of unused snags. We nevertheless found that woodpeckers chose trees that were larger in diameter than adjacent potential nest trees. There are many possible advantages to nesting in larger trees. Larger trees may contain more places to excavate. Larger trees are probably older and therefore more decayed. Additionally, larger trees enable construction of cavities with thicker walls, which provide thermal insulation, protection from predators, and lower probability of breaking at cavity height (Kilham 1971; Miller and Miller 1980).

Ranges of tree diameters used by Downy and Hairy woodpeckers and Yellow-bellied Sapsuckers in our study are comparable to ranges found in the literature (Conner et al. 1975; Evans and Conner 1979; Thomas et al. 1979). However, in our study, $55 \%$ of trees used by Red-bellied Woodpeckers and $20 \%$ of trees used by Red-headed Woodpeckers were below the observed optimum range of nest tree diameters given for these species (Evans and Conner 1979). Selection may be different for these species in our study area or our sample may not be representative. However, it is possible that our results suggest a shortage in the study area of large diameter trees required by Red-bellied and Redheaded woodpeckers. 
TABLE 4. Characteristics that significantly differed (chi-square tests of homogeniety) for seven species of woodpecker in upper midwestern oak forests. 1997-1998.

\begin{tabular}{|c|c|c|}
\hline & \multicolumn{2}{|c|}{$\begin{array}{c}\% \text { of trees with } \\
\text { characteristic }\end{array}$} \\
\hline & $\begin{array}{l}\text { Nest } \\
\text { trees }\end{array}$ & $\begin{array}{c}\text { Random } \\
\text { Potential } \\
\text { Nest Tree }^{\mathrm{a}}\end{array}$ \\
\hline \multicolumn{3}{|l|}{ Downy Woodpecker $(n=44)$} \\
\hline Dead or partly dead ${ }^{\mathrm{b}^{*}}$ & 84 & 66 \\
\hline Broken forked top ${ }^{* *}($ d.f. $=2)$ & 25 & 6 \\
\hline Tree elm or Trembling Aspen ${ }^{* * *}$ & 59 & 18 \\
\hline Old cavities present ${ }^{* * *}$ & 41 & 4 \\
\hline Sapwood fungus present* & 32 & 11 \\
\hline 3 or more decay indicators ${ }^{* * *}$ & 61 & 28 \\
\hline $0-25 \%$ bark cover ${ }^{* * *}$ & 39 & 9 \\
\hline \multicolumn{3}{|l|}{ Hairy Woodpecker $(n=22)$} \\
\hline Tree elm or Trembling Aspen ${ }^{* * *}$ & 64 & 18 \\
\hline Old cavities present ${ }^{* * *}$ & 45 & 4 \\
\hline Heartwood decay fungus present ${ }^{* * *}$ & 45 & 13 \\
\hline Without significant dead portion ${ }^{* * *}$ & 36 & 9 \\
\hline 3 or more decay indicators"** & 68 & 28 \\
\hline \multicolumn{3}{|l|}{ Red-bellied Woodpecker $(n=29)$} \\
\hline Tree elm or Trembling Aspen ${ }^{* * * *}$ & 52 & 18 \\
\hline Broken forked top $^{* * *}$ (d.f. $=2$ ) & 28 & 6 \\
\hline Old cavities present ${ }^{* * *}$ & 55 & 4 \\
\hline 3 or more decay indicators ${ }^{* * *}$ & 66 & 28 \\
\hline $0-25 \%$ bark cover ${ }^{* *}$ & 31 & 9 \\
\hline \multicolumn{3}{|l|}{ Red-headed Woodpecker $(n=20)$} \\
\hline Tree elm or Trembling Aspen ${ }^{* * *}$ & 80 & 18 \\
\hline Dead or partly dead* & 90 & 66 \\
\hline Broken fork $^{* *}($ d.f. $=2)$ & 30 & 6 \\
\hline Old cavities present ${ }^{* * *}$ & 70 & 4 \\
\hline 3 or more decay indicators ${ }^{* * *}$ & 70 & 28 \\
\hline $0-25 \%$ bark cover ${ }^{* * *}$ & 70 & 9 \\
\hline \multicolumn{3}{|l|}{ Yellow-bellied Sapsucker $(n=42)$} \\
\hline Tree alive ${ }^{* * *}$ & 88 & 34 \\
\hline Top intact ${ }^{* * *}($ d.f. $=2)$ & 98 & 62 \\
\hline Tree Trembling Aspen ${ }^{* * *}$ & 88 & 8 \\
\hline Old cavities present ${ }^{* * * *}$ & 67 & 4 \\
\hline Heartwood decay fungus present ${ }^{* * *}$ & 95 & 13 \\
\hline No significant dead portion ${ }^{* * *}$ & 86 & 9 \\
\hline 3 or more decay indicators ${ }^{* * *}$ & 74 & 28 \\
\hline $75-100 \%$ bark cover* & 95 & 81 \\
\hline
\end{tabular}

${ }^{a} n=137$ random potential nest trees

${ }^{\mathrm{b}}$ d.f. $=1$ unless otherwise indicated

* $P<0.05$

** $P<0.1$

** $P<0.001$

Generally, woodpeckers with larger body sizes require larger diameter nest trees (Conner et al. 1975). Similar to other studies (Conner et al. 1975; Brawn et al. 1984; Raphael and White 1984; Li and Martin 1991), we found a significant difference among woodpecker species in nest tree diameter, which generally corresponded with woodpecker body size.

Woodpeckers chose nest trees that were taller than adjacent potential nest trees. When taller trees are available, nest heights tend to be higher because higher nests make nest cavities less easily detected and reached by predators (Miller and Miller 1980). A nest located high in the tree gives the woodpecker more time to dislodge or discourage a predator climbing the trunk (Kilham 1971). Other investigators have also found that woodpeckers choose taller trees (Welsch and Howard 1983; Zarnowitz and Manuwal 1985; Sedgewick and Knopf 1990; Joy 2000).

There were no significant differences among woodpecker species in nest tree height or nest hole height in our study. However, other investigators have found differences in nest tree height or nest hole height (Conner et al. 1975; Stauffer and Best 1982; Brawn et al. 1984; Raphael and White 1984). Harestad and Keisker (1989) explained difference in nest tree height among woodpeckers as a consequence of different preferences for tree condition.

\section{Tree Condition}

Trees used by woodpeckers had several indicators of heartwood decay. Soft heartwood is a necessity for excavation (Kilham 1971), and tree wounds, such as branch stubs, tree scars, and old cavities, provide access to the heartwood and serve as entry points for fungi. Number of decay indicators present depended in part on the tree species. It appeared that tree species with especially hard wood, like oaks and cherries, required more decay for the wood to become suitably softened for excavation.

Woodpeckers often chose trees with old cavities. Old cavities are clear indicators of past suitability and also serve as entry points for additional heartwood fungi. Return of birds to the same tree is likely also a function of tree availability and territoriality. One active Yellow-bellied Sapsucker nest tree contained 16 old cavities.

Differences in condition of trees chosen for nesting by each species may be explained by differences in the excavation abilities of the species (Spring 1965). Downy Woodpeckers are weak excavators and often choose trees with some sapwood fungi (Harestad and Keisker 1989; this study). Presence of sapwood fungi suggests that the outer wood is soft, making the wood easier to excavate. However, we found trees with extensive sapwood decay were not used for nesting. Such trees may not offer adequate protection of the nest cavity (Kilham 1971; Conner et al. 1976). Yellow-bellied Sapsuckers most often nested in living trees with sound sapwood and several indicators of heartwood decay. Fomes igniarius, a heartwood fungus that attacks live wood, especially of Trembling Aspen, softens the heartwood but leaves the sapwood sound (Harestad and Keisker 1989). Nearly all Yellow-bellied Sapsucker nest trees had conks of Fomes igniarius present.

\section{Tree Species}

American Elms and Trembling Aspens were most frequently used for nesting. Although we found no nests in Slippery Elms, there were more dead Slip- 
TABLE 5. Diameter at breast height (dbh) and height of nest trees of seven species of woodpecker upper in upper midwestern oak forests, 1997-1998.

\begin{tabular}{|c|c|c|c|c|c|c|c|c|c|}
\hline & \multirow[b]{2}{*}{$n$} & \multicolumn{4}{|c|}{ Nest Tree dbh $(\mathrm{cm})$} & \multicolumn{4}{|c|}{ Nest Tree Height (m) } \\
\hline & & Mean & SE & Min & $\operatorname{Max}$ & Mean & $\mathrm{SE}$ & Min & Max \\
\hline Yellow-bellied Sapsucker & 42 & $30 \mathrm{~A}$ & 0.80 & 19 & 42 & $20 \mathrm{~A}$ & 0.62 & 8 & 34 \\
\hline Hairy Woodpecker & 22 & $33 \mathrm{~A}$ & 3.0 & 20 & 76 & $17 \mathrm{~A}$ & 1.1 & 8 & 24 \\
\hline Downy Woodpecker & 44 & $35 \mathrm{AB}^{\mathrm{a}}$ & 1.9 & 16 & 63 & $17 \mathrm{~A}$ & 0.91 & 6 & 29 \\
\hline Pileated Woodpecker & 4 & $69 \mathrm{BC}$ & 23 & 42 & 127 & $21 \mathrm{~A}$ & 50 & 9 & 29 \\
\hline Northern Flicker & 4 & $69 \mathrm{BC}$ & 22 & 38 & 121 & $18 \mathrm{~A}$ & 2.6 & 14 & 23 \\
\hline Red-bellied Woodpecker & 29 & $47 \mathrm{C}$ & 5.0 & 23 & 137 & $18 \mathrm{~A}$ & 1.1 & 8 & 29 \\
\hline Red-headed Woodpecker & 20 & $54 \mathrm{C}$ & 7.0 & 28 & 168 & $19 \mathrm{~A}$ & 1.2 & 7 & 27 \\
\hline All woodpecker nests & 101 & 39 & 2.2 & 16 & 168 & 18 & 0.5 & 6 & 34 \\
\hline
\end{tabular}

${ }^{a}$ Means with the same letter were not significantly different $(P>0.05)$ by multiple comparison procedure based on ranks

TABLE 6. Significant differences (chi-square tests) among nest tree characteristics of five species of woodpecker in upper upper midwestern oak forests 1997-1998.

\begin{tabular}{|c|c|c|c|c|c|c|c|c|c|}
\hline & \multirow[b]{2}{*}{$n$} & \multirow[b]{2}{*}{$\begin{array}{c}\text { Species } \\
\text { Trembling } \\
\text { Aspen }\end{array}$} & \multirow[b]{2}{*}{$\begin{array}{l}\text { Heartwood } \\
\text { fungus } \\
\text { present }\end{array}$} & \multicolumn{4}{|c|}{$\%$ of nest trees with each characteristic } & \multirow[b]{2}{*}{$\begin{array}{l}\text { Tree } \\
\text { alive }\end{array}$} & \multirow[b]{2}{*}{$\begin{array}{c}\text { Tree Top } \\
\text { intact }\end{array}$} \\
\hline & & & & $\begin{array}{l}\text { Sapwood } \\
\text { fungus } \\
\text { present }\end{array}$ & $\begin{array}{c}\text { Significant } \\
\text { dead } \\
\text { portion }\end{array}$ & $\begin{array}{l}\text { Livewood } \\
>75-100 \%\end{array}$ & $\begin{array}{l}\text { Bark cover } \\
>75-100 \%\end{array}$ & & \\
\hline Downy Woodpecker & 44 & $11 \mathrm{~A}^{\mathrm{a}}$ & $16 \mathrm{~A}$ & $32 \mathrm{~A}$ & $95 \mathrm{~A}$ & $18 \mathrm{~A}$ & $52 \mathrm{~A}$ & $16 \mathrm{~A}$ & $48 \mathrm{~A}$ \\
\hline Red-bellied Woodpecker & 29 & $11 \mathrm{~A}$ & $24 \mathrm{AC}$ & $28 \mathrm{AB}$ & $100 \mathrm{~A}$ & $31 \mathrm{~A}$ & $66 \mathrm{~A}$ & $24 \mathrm{~A}$ & $24 \mathrm{~A}$ \\
\hline Red-headed Woodpecker & 20 & $27 \mathrm{~A}$ & $10 \mathrm{AC}$ & $5 \mathrm{AB}$ & $90 \mathrm{AB}$ & $10 \mathrm{~A}$ & $30 \mathrm{~A}$ & $10 \mathrm{~A}$ & $50 \mathrm{~A}$ \\
\hline Hairy Woodpecker & 22 & $17 \mathrm{~A}$ & $45 \mathrm{C}$ & $14 \mathrm{AB}$ & $64 \mathrm{~B}$ & $41 \mathrm{~A}$ & $64 \mathrm{~A}$ & $36 \mathrm{~A}$ & $55 \mathrm{~A}$ \\
\hline Yellow-bellied Sapsucker & 42 & $88 \mathrm{~B}$ & $95 \mathrm{~B}$ & $2 \mathrm{~B}$ & $14 \mathrm{C}$ & $88 \mathrm{~B}$ & $95 \mathrm{~B}$ & $88 \mathrm{~B}$ & $98 \mathrm{~B}$ \\
\hline
\end{tabular}

${ }^{a}$ Percentages with same letter reflect means that were not significantly different $(P>0.05)$ by multiple comparison.

pery Elms available than dead American Elms. This observation suggests that American Elms have decay characteristics that suit woodpeckers.

The propensity for Yellow-bellied Sapsuckers to nest in aspens has been well documented (Kilham 1971; Thomas et al. 1979; Runde and Capen 1987; Harestad and Keisker 1989). Aspens may be more prone to decay than most other hardwoods. In our study area, it appears that Yellow-bellied Sapsuckers are weak excavators, as suggested by Jackman (1974), so the extensive heartwood decay of mature aspen are suitable.

Red-headed Woodpeckers primarily nested in American Elms, especially large, barkless elms with many broken branches. Dutch elm disease may have benefited Red-headed Woodpeckers by creating highly suitable snags (Jackson 1976). However, the disease widely eliminated American Elm as a major forest species, and in the future, woodpeckers will have few dead elms for nesting. Elms that died from Dutch elm disease are losing suitability for nesting as tree decay becomes extensive; additional dead elms are lost from blow-down and human removal. Red-headed Woodpeckers will need to rely more heavily on other tree species for nesting or face continued decline. Abundance of Red-headed Woodpeckers in Minnesota has been significantly declining since 1966 (Green 1995).
Downy, Hairy, and Red-bellied Woodpeckers showed more variation in tree species chosen. However, caution should be observed before applying these tree species results to other geographic areas because tree species selected for nesting by these species vary by locality, availability, and tree condition (Bull et al. 1980).

\section{Management Implications}

It is important that suitable cavity trees are left during timber harvest. The value of such trees extends beyond their importance to woodpeckers. In upper midwestern oak forests, secondary cavity-dwelling wildlife like the Great-crested Flycatcher, Tufted Titmouse (Baeolophus bicolor), House Wren (Troglodytes aedon), White-breasted Nuthatch, Barred Owl, and Southern Flying Squirrel (Glaucomys volans) all use old woodpecker holes for nesting. Studies have shown that lack of suitable nest sites is a limiting factor for many species of cavity-nesting birds (Cunningham et al. 1980; Zarnowitz and Manuwal 1985; Dobkin et al. 1995).

Our study does not address number of trees to leave for wildlife during timber harvest, but it does offer insight into the characteristics of trees. According to our results, emphasis should be placed on retaining trees with sound sapwood that also show signs of heartwood decay (e.g. broken tops). We recommend 
retaining living as well as dead trees, but living trees need to be maintained on long rotations to develop suitable decay characteristics for nesting. Indeed, old growth conditions may take $>100$ years to develop in both oak-hickory forests and aspen forests (Hardin and Evans 1977; Winternitz and Cahn 1983). Because trees with old woodpecker nest cavities are especially important for nesting, trees with old cavities should be retained.

Trees of various size classes should be retained during harvest. It is important that diameters near the mean for each woodpecker species are provided to encourage excavation of normal-sized cavities and reduce death of nestlings due to overcrowding (Kilham 1968; Evans and Connor 1979; Miller and Miller 1980). Small diameter trees may provide foraging substrate, but they should not be considered substitutes for larger diameter cavity trees. If choices need to be made about which trees to retain, the larger diameter and taller trees should be retained.

In our study, certain tree species, especially American Elm and Trembling Aspen, were used more often than others for nesting. However, undue emphasis should not be placed on importance of tree species. Most woodpeckers are restricted to certain tree species for nesting but require certain levels of decay, which vary by tree species.

Our study suggests that generic management for all woodpecker species may not be adequate because individual species have specific nest tree requirements. However, it may be possible to meet a diversity of species needs if forest managers retain many large trees with a range of decay conditions. Although this paper focuses on the suitability of individual trees for woodpecker nesting, we discuss the role of the larger forest context in another paper (Adkins Giese and Cuthbert 2003). More research is needed on longevity of trees left for wildlife during harvest and the longterm impacts of existing forest management practices on wildlife. However, recommendations from this study, if adopted, would enhance conditions for cavity-dwelling wildlife in upper midwestern oak forests.

\section{Acknowledgments}

The Minnesota Nongame Wildlife Tax Checkoff and the Reinvest In Minnesota Program, through the Minnesota Department of Natural Resources, Division of Fish and Wildlife, Natural Heritage and Nongame Research Program, provided funding for the fieldwork. Additional support came from Minnesota Forest Resources Council, the Gordon Gullion Scholarship, and Dayton-Wilkie Natural History Fund of Bell Museum of Natural History, Minnesota Agricultural Experiment Station. Partial funding for the project was appropriated for the Minnesota Forest Bird Diversity Initiative by the Minnesota State Legislature from the Environmental Trust Fund as recommended by the Legislative Commission on Minneso- ta Resources. We thank S. Gale, M. Friberg, and M. Knutson for assistance in the field study. G. Oehlert and C. Bingham provided statistical advice. We thank D. Andersen and G. Niemi for input and assistance with various aspects of the research.

\section{Literature Cited}

Adkins Giese, C. L. 1999. Woodpecker nest site selection in oak forests of the Driftless Area in the Upper Midwest. M.S. thesis, University of Minnesota, St. Paul.

Adkins Giese, C. L., and F. J. Cuthbert. 2003. Influence of surrounding vegetation on woodpecker nest tree selection in oak forests of the Upper Midwest, USA. Forest Ecology \& Management 179: 523-534.

Brawn, J. D., B. Tannenbaum, and K. E. Evans. 1984. Nest site characteristics of cavity nesting birds in central Missouri. U.S. Forest Service Research Note NC-3 14.

Brunden, M. N. 1972. The analysis of non-independent $2 \times 2$ tables from $2 \times \mathrm{C}$ tables using rank sums. Biometrics 28: 603-607.

Bruns, H. 1960. The economic importance of birds in forests. Bird Study 7: 193-209.

Bull, E. L., and E. C. Meslow. 1977. Habitat requirements of the Pileated Woodpecker in northwestern Oregon. Journal of Forestry 75: 335-37.

Bull, E. L., A. S. Twombly, and T. M. Quigley. 1980. Perpetuating snags in managed mixed conifer forests of the Blue Mountains, Oregon. Pages 325-336 in Management of western forests and grasslands for nongame birds: workshop proceedings. R. M. DeGraaf, Technical Coordinator. U.S. Forest Service General Technical Report INT-86.

Conner, R. N. 1975. Orientation of entrances to woodpecker nest cavities. The Auk 92: 371-374.

Conner, R. N. 1978. Snag management for cavity nesting birds. Pages 120-128 in Proceedings of workshop on management of southern forests for nongame birds. R. M. DeGraaf, Technical Coordinator. U.S. Forest Service General Technical Report SE-14.

Conner, R. N., and C. S. Adkisson. 1977. Principal Components Analysis of woodpecker nesting habitat. Wilson Bulletin 89: 122-129.

Conner, R. N., R. G. Hooper, H. S. Crawford, and H. S. Mosby. 1975. Woodpecker nesting habitat in cut and uncut woodlands in Virginia. Journal of Wildlife Management 39: 144-150.

Conner, R. N., O. K. Miller, Jr., and C. S. Adkisson. 1976. Woodpecker dependence on trees infected by fungal heart rots. Wilson Bulletin 88: 575-581.

Cunningham, J. B., R. P. Balda, and W. S. Gaud. 1980. Selection and use of snags by secondary cavity nesting birds of the ponderosa pine forest. U.S. Forest Service Research Paper RM-222.

Dobkin, D. S., A. C. Rich, and J. A. Pretare. 1995. Nestsite relationships among cavity-nesting birds of riparian and snowpocket aspen woodlands in the northwestern Great Basin. Condor 97: 694-707.

Dunn, O. J. 1964. Multiple comparisons using rank sums. Technometrics 6: 241-252.

Evans, K. E., and R. N. Conner. 1979. Snag management. Pages 214-225 in Proceedings of workshop on management of north central and northeast forests for nongame birds. R. M. DeGraaf, Technical Coordinator. U.S. Forest Service General Technical Report NC-51. 
Green, J. C. 1995. Birds and forests: A management and conservation guide. Minnesota Department of Natural Resources, St. Paul, Minnesota.

Hardin, K. I., and K. E. Evans. 1977. Cavity nesting bird habitat in the oak-hickory forest, a review. U.S. Forest Service General Technical Report NC-30.

Harestad, A. S., and D. G. Keisker. 1989. Nest tree use by primary cavity nesting birds in south central British Columbia. Canadian Journal of Zoology 67: 1067-1073.

Jackman, S. M. 1974. Woodpeckers of the Pacific Northwest: their characteristics and their role in the forests. M.S. thesis, Oregon State University, Corvallis.

Jackson, J. A. 1976. A comparison of some aspects of the breeding ecology of Red-Headed and Red-bellied Woodpeckers in Kansas. Condor 78: 67-76.

Joy, J. B. 2000. Characteristics of nest cavities and nest trees of the red-breasted sapsucker in coastal montane forests. Journal of Field Ornithology 71: 525-530.

Kilham, L. 1968. Reproductive behavior of Hairy Woodpeckers. II. Nesting and habitat. Wilson Bulletin 80: 286305.

Kilham, L. 1971. Reproductive behavior of Yellow-bellied Sapsuckers. I. Preferences for nesting in Fomes-infected aspens and nest hole interrelations with flying squirrels, raccoons, and other animals. Wilson Bulletin 83: 159171.

Li, P., and T. E. Martin. 1991. Nest-site selection and nesting success of cavity nesting birds in high elevation forest drainages. The Auk 108: 405-418.

Mannan, W. R., E. C. Meslow, and H. M. Wright. 1980. Use of snags by birds in Douglas-fir forests, western Oregon. Journal of Wildlife Management 44: 787-797.

Marschner, F. J. 1974. The original vegetation of Minnesota (map). U.S. Forest Service North Central Forest Experiment Station, St. Paul. Redraft of the original 1930 edition.

McClelland, B. R., and S. S. Frissell. 1975. Identifying forest snags useful for hole-nesting birds. Journal of Forestry 73: 414-417.

Miettinen, O. S. 1968. On the matched pairs design in the case of all-or-none responses. Biometrics 24: 339-352.

Miller, E., and D. R. Miller. 1980. Snag use by birds. Pages 337-356 in Proceedings of a workshop on management of western forests and grasslands for nongame birds. R. M. DeGraaf, Technical Coordinator. U.S. Forest Service General Technical Report INT-86.

Raphael, M. G., and M. White. 1984. Use of snags by cavity nesting birds in the Sierra Nevada. Wildlife Monographs 86: 1-66.

Reller, A. W. 1972. Aspects of behavioral ecology of the Red-headed and Red-bellied woodpeckers. American Midland Naturalist 88: 270-290.

Runde, D. E., and D. E. Capen. 1987. Characteristics of northern hardwood trees used by cavity nesting birds. Journal of Wildlife Management 51: 217-223.

Scott, V. E. 1978. Characteristics of ponderosa pine snags used by cavity-nesting birds in Arizona. Journal of Forestry 76: $26-28$

Scott, V. E., and J. L. Oldemeyer. 1983. Cavity nesting bird requirements and response to snag cutting in Ponderosa pine. Pages 19-25 in Proceedings of symposium on snag habitat management. J. W. Davis and G. A. Goodwin, Technical Coordinators. U.S. Forest Service General Technical Report RM-99.

Scott, V. E., J. A. Whelan, and R. R. Alexander. 1978. Dead trees used by cavity-nesting birds on the Fraser Experimental Forest: a case history. U.S. Department of Agriculture, Forest Service, Rocky Mountain Research Station, Research Note RM-360: 1-4.

Scott, V. E., J. A. Whelan, and P. L. Svoboda. 1980. Cavity nesting birds and forest management. Pages 311-324 in Proceedings of workshop on management of western forests and grasslands for nongame birds. R. M. DeGraaf, Technical Coordinator. U.S. Forest Service General Technical Report INT-86.

Sedgwick, J. A., and F. L. Knopf. 1986. Cavity nesting birds and the cavity tree resource in plains cottonwood bottomlands. Journal of Wildlife Management 50: 247-52.

Sedgwick, J. A., and F. L. Knopf. 1990. Habitat relationships and nest site characteristics of cavity nesting birds in cottonwood floodplains. Journal of Wildlife Management 54: 112-124.

Schreiber, B., and D. S. deCalesta. 1992. The relationship between cavity nesting birds and snags on clearcuts in western Oregon. Forest Ecology \& Management 50: 299316.

Spring, L. W. 1965. Climbing and pecking adaptations in some North American woodpeckers. Condor 67: 457-488.

Stauffer, D. F., and L. B. Best. 1982. Nest-site selection by cavity nesting birds of riparian habitats in Iowa. Wilson Bulletin 94: 329-337.

Swallow, S. K., R. J. Gutierrez, and R. A. Howard, Jr. 1986. Primary cavity-site selection by birds. Journal of Wildlife Management 50: 576-583.

Thomas, J. W., R. G. Anderson, C. Maser, and E. L. Bull. 1979. Wildlife habitats in managed forests: the Blue Mountains of Oregon and Washington. U.S. Forest Service Agriculture Handbook 553: 60-77.

Welsch, C. J. E., and R. A. Howard, Jr. 1983. Characteristics of snags influencing their selection by cavity nesting birds. Transactions of Northeast Fish and Wildlife Conference 40: 177.

Winternitz, B. L., and H. Cahn. 1983. Nest holes in live and dead aspen. Pages 102-107 in Proceedings of symposium on snag habitat management. J. W. Davis and G. A. Goodwin, Technical Coordinators. U.S. Forest Service General Technical Report RM-99.

Zarnowitz, J. E., and D. A. Manuwal. 1985. The effects of forest management on cavity nesting birds in northwestern Washington. Journal of Wildlife Management 49: 255-63.

Zeedyk, W. D. 1983. Managing snag habitats on southwestern national forests. Pages 2-3 in Proceedings of symposium on snag habitat management. Technical Coordinators J. W. Davis and G. A. Goodwin. U.S. Forest Service General Technical Report RM-99.

Received 27 February 2004

Accepted 24 March 2005 